\section{GRYILLIDAE.}

Since my paper on the "Gryllidae of Indiana"* appeared, seven additional species have been taken, so that now 22 are known to occur in Vigo County. From what is known of the life history of the mole crickets, the two species, Gryllotalpa borealis Burm., and G. columbia Scudder, undoubtedly exist through the winter in the larval stage, though I have never happened upon them in that season.

A careful study of the members of the genus Gryllus during the last three years has developed the fact that 4 species, namely : G. neglectus Scudder, abbreviatus Serville, pennsylvanicus Burm., and luctuosus Serville inhabit the county. The last two may be different forms of the same species, but that the first 3 are distinct, there is, to my mind, no doubt.

Of these, the eggs of neglectus and pennsylvanicus, and probably those of luctuosus, hatch in autumn, and the young in numbers may be found beneath logs, rails, and other protective cover during the entire winter. Often as many as a dozen are sheltered beneath the same object, each at the bottom of a cone-shaped pit, quite similar to the one made in loose sand by the larva of the ant lion, Myrmeleon obsoletus Say.

$G$. neglectus reaches maturity as early as May 5 th, the males having been heard chirping on that date. Pennsylvanicus and luctuosus are full grown about the 25th of May, while the adults of abbreviatus, from eggs hatched in spring, do not occur until the last week in July.

\title{
EGGS OF THE LONG-NOSED OX-LOUSE, HAEMATOPINUS VITULA L.
}

\author{
BY F. L. HARVEY, ORONO, ME.
}

Professor Osborn says in his monograph "Pedicula and Mallophaga affecting Man and the Lower Animals" (Bull. 7, Div. Ent. U. S. Dept. Agric. p. 18) "that the eggs of this species have not been described, and we have not had the good fortune to discover them." Having been more fortunate we are able to submit the following

* Proc. Ind. Acad. Sci., r8gr. account of the eggs of this species. The Long-nosed ox-louse has been quite bad this winter in herds in the vicinity of Thomaston, Me. At our request Mr. A. W. Batchelder of Thomaston collected some hair from the infested animals, and upon this we found three egg-shells with the operculum off, but the form, sculpture, manner and place of attachment to the hairs seemed perfect. 
Description. Elongate oval, tapering toward the base. Slightly bulging on the side away from the hair in one specimen, or in the others narrower and more symmetrical. About two and a half times as long as wide. The empty shell hyaline and beautifully sculptured with hexagonal reticulations. The hexagons somewhat variable in size and perfectness in different

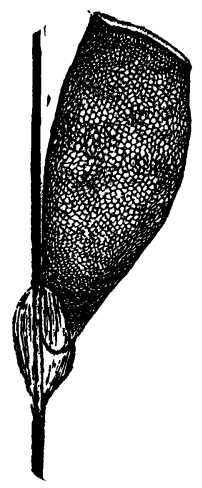

parts of the shell, but average ones about onetwentieth of the width of the shell. The surface apparently smooth, the angles of the reticulations not beset with points as in the eggs of the Short-nosed ox-louse. Attached to the hair by a cement mass about one-third the length of the egg, as shown in the figure. The cement mass varies in shape, the distance it extends along the hair and the remoteness of the attachment from the root of the hair. The sloping base of the egg is included more or less in the cement mass, and the egg stands somewhat obliquely outward from the hair.

Below we give measurements of the three eggs observed. The figure, drawn to scale by the writer, shows the egg enlarged 40 times.

Measurements: Specimen (a), length, .863 $\mathrm{mm}$; width, $.38 \mathrm{~mm}$; width of operculum, $.265 \mathrm{~mm}$.; from base of hair, $5 \mathrm{~mm}$.; cement mass, $.345 \mathrm{~mm}$.; hexagonal reticulations of shell, .02 $\mathrm{mm}$.

Specimen (b), length, $.805 \mathrm{~mm}$; width, $.379 \mathrm{~mm}$.; width of operculum, .253 mm.; from base of hair, $5.75 \mathrm{~mm}$.; cement mass, $.288 \mathrm{~mm}$.

Specimen (c), length, $.805 \mathrm{~mm}$; width, $.379 \mathrm{~mm}$.; width of operculum, .265 mm.; from base of hair, Io $\mathrm{mm}$. ; cement mass, $.312 \mathrm{~mm}$.

\section{ON THE VALIDITY OF THE TACHINID GENUS CELATORIA.}

BY D. W. COQUILLETT, WASHINGTON, D. C.

On page 235 of the second volume of Insect life, the writer erected the genus Celatoria for the reception of an interesting Californian species of Tachina fly that preys upon the adults of the destructive Diabrotica soror, as many as one-third of these beetles sometimes falling a prey to the attacks of this parasite. The validity of this genus has been called in question by the well- known authors, Messrs. Brauer and Bergenstamm, who cite it as a synonym of the previously described genus Besseria (Die zweiflugler des Kaiserlichen Museums zu Wien, vi, 154 and I89; also p. 220, where the species, crawiii Coq., is erroneously credited to C. H. T. Townsend). That these two genera are very distinct from each other may easily be seen by the following 

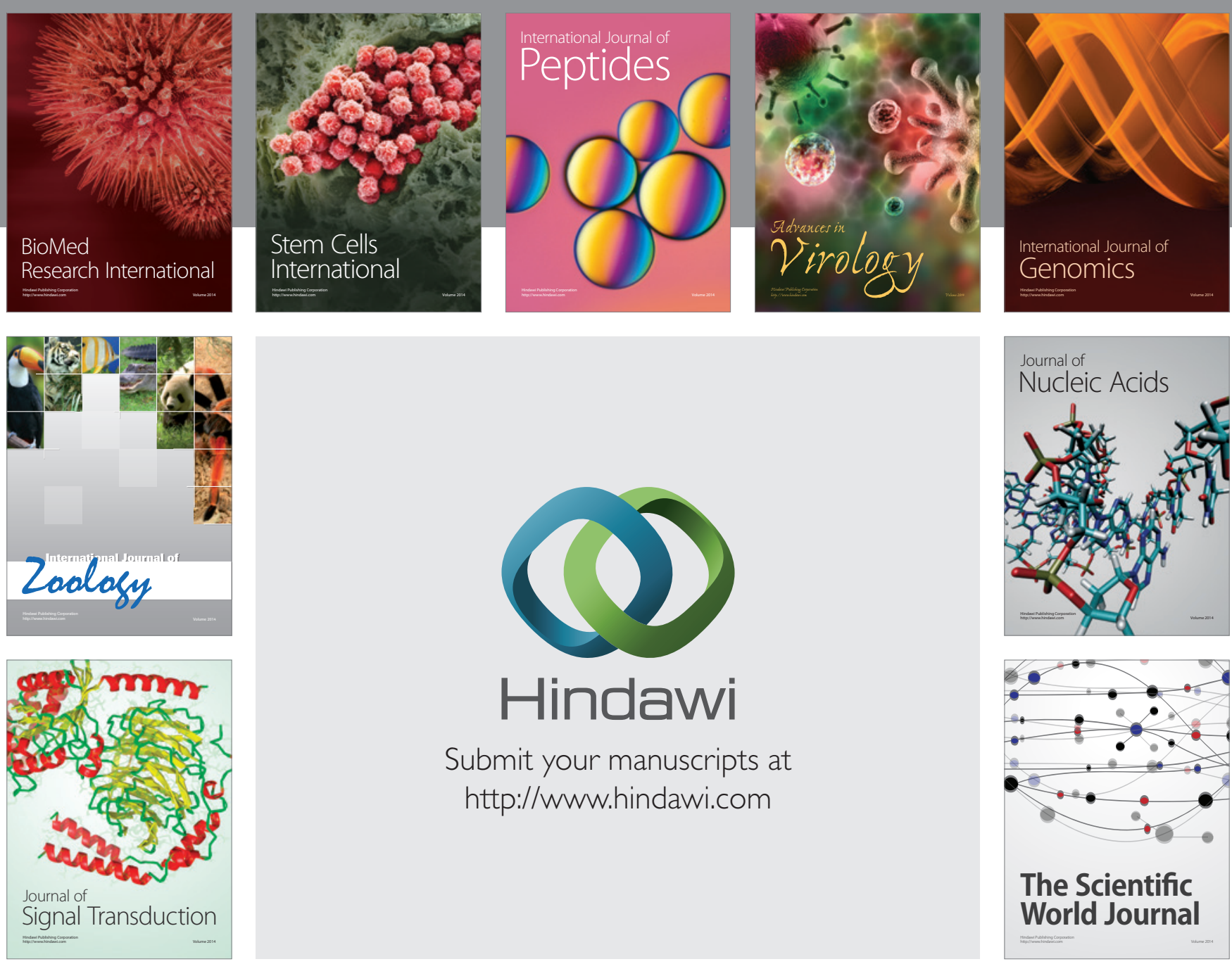

Submit your manuscripts at

http://www.hindawi.com
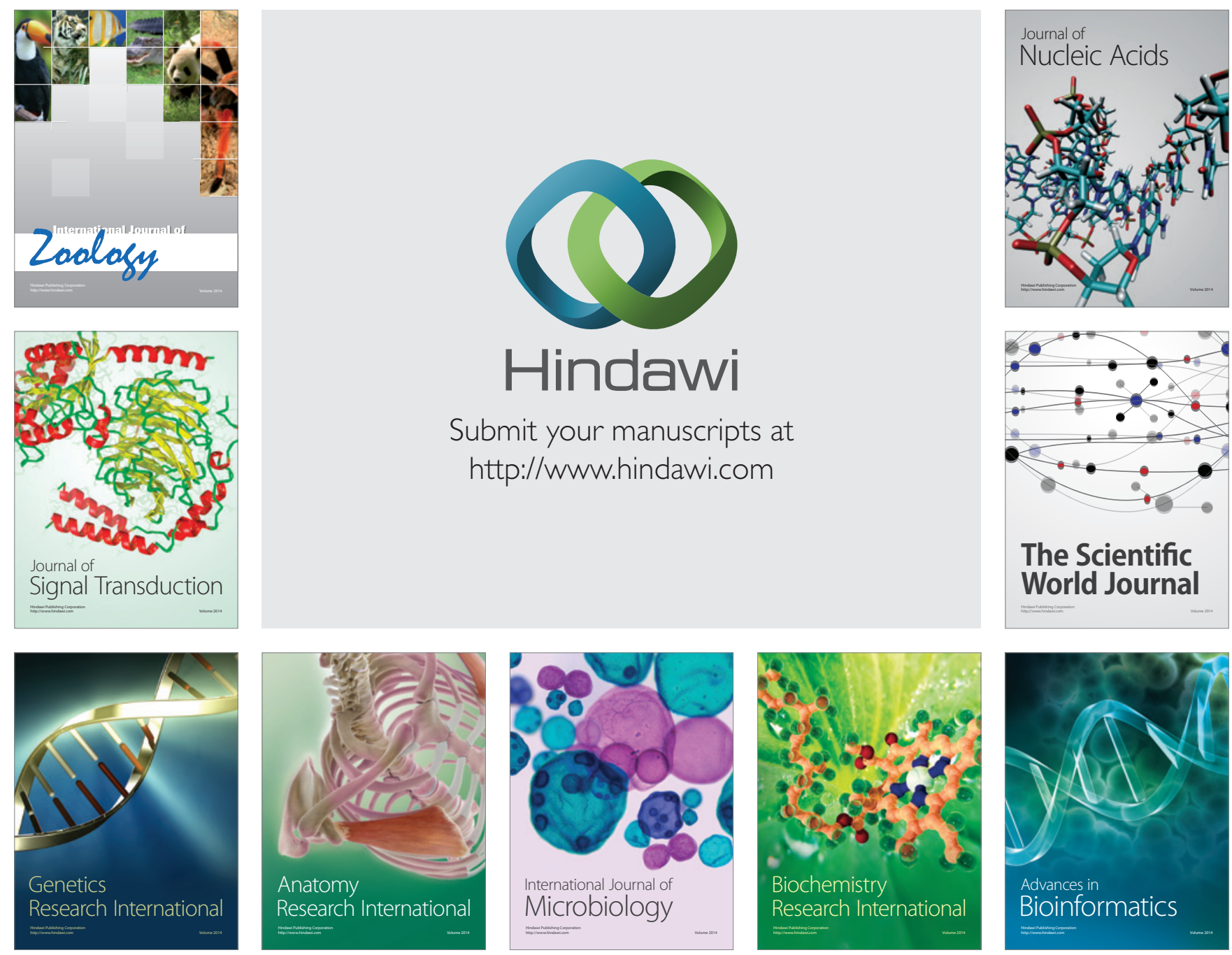

The Scientific World Journal
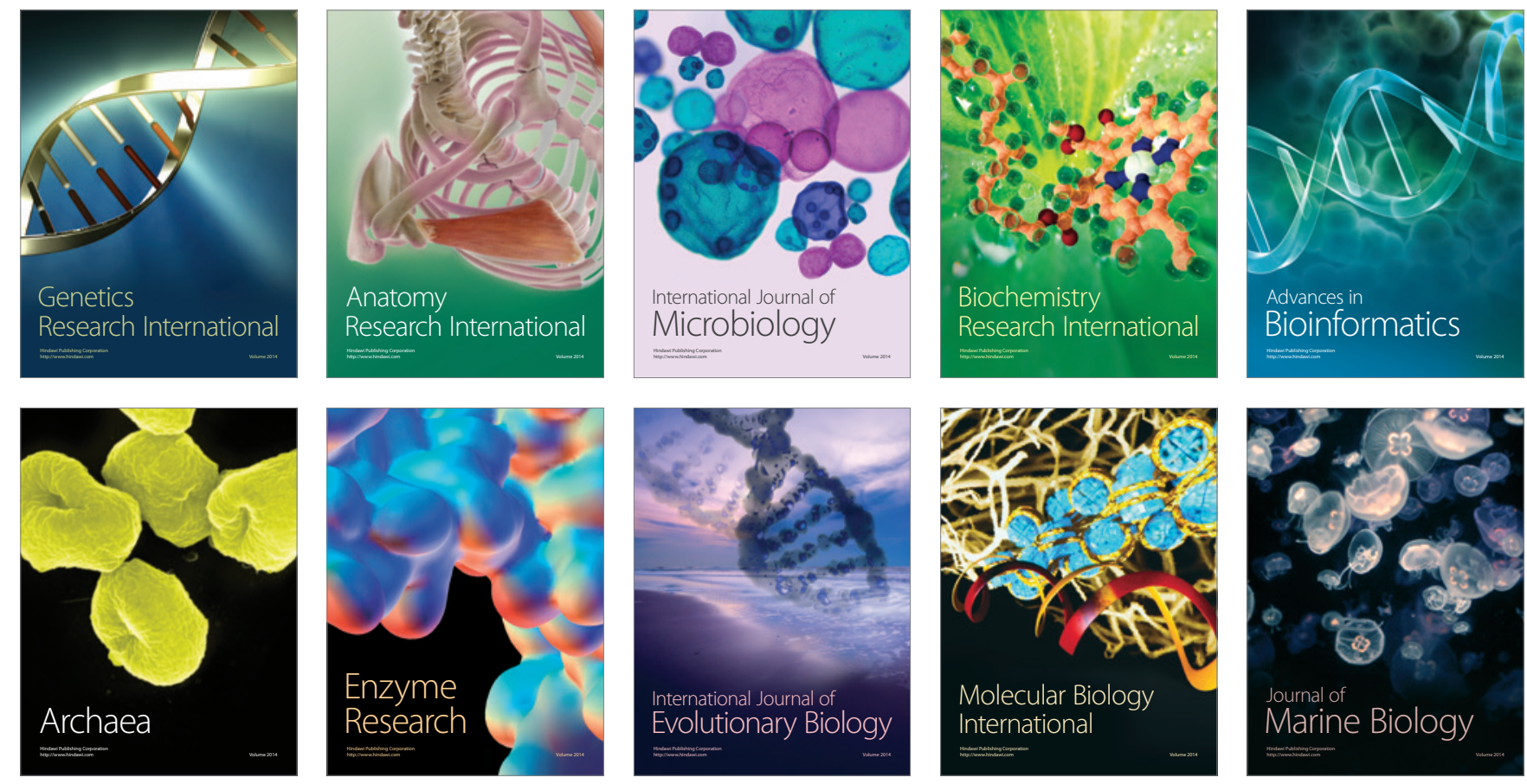